\title{
Density and reproduction of the Queen Conch Eustrombus gigas (Mesogastropoda: Strombidae) at Cabo Cruz, Desembarco del Granma National Park, Cuba
}

\author{
Yuself R. Cala ${ }^{1}$, Alberto de Jesús-Navarrete ${ }^{2}$, Frank A. Ocaña ${ }^{3}$ \& José Oliva-Rivera ${ }^{2}$ \\ 1. Programa de doctorado en Ecología y Desarrollo Sustentable, El Colegio de la Frontera Sur, Unidad Chetumal. Ave. \\ Centenario, Km. 5,5, Col. Antorchista. Chetumal. Quintana Roo, México; sgigas21824@gmail.com \\ 2. Departamento de Aprovechamiento y Manejo de Recursos Acuáticos, El Colegio de la Frontera Sur (ECOSUR), \\ Unidad Chetumal, México; anavarre@ecosur.mx, joliva@ecosur.mx \\ 3. Centro de Investigaciones y Servicios Ambientales y Tecnológicos (CISAT), Holguín, Cuba; frankocisat@gmail.com
}

Received 15-II-2012. C Corrected 20-IX-2012. Accepted 18-X-2012.

\begin{abstract}
Densidad y reproducción de la concha reina Eustrombus gigas (Mesogastropoda: Strombidae) en Cabo Cruz, Parque Nacional Desembarco del Granma, Cuba. The queen conch Eustrombus gigas is an important fisheries resource in the Caribbean region. In Cuba Island the studies about this resource are very scarce and particularly in the Southeastern regions of the country. With the aim to get important fishery information about this gastropod, adult Queen Conch density and frequency of reproductive activity were evaluated in Cabo Cruz, Cuba, during 2009-2010. Data from three seasons were obtained (rainy, dry and cold fronts periods) from three different areas: Farito, Guafe and Laguna. The highest density was observed in cold fronts season (468.5ind./ha) and the lowest occurred during the dry season (268.5ind./ha). The highest density was reported at Laguna (520.4ind./ha) and the lowest at Farito (290.9ind./ha). In total, 158 reproductive events were observed. The highest frequency was reported in rainy season (36\%), followed by dry $(9 \%)$ and cold fronts (5\%) seasons. Reproductive behavior (mating and egg laying) was related to temperature and photoperiod. Reproductive activity was observed during the whole year, which suggests the existence of an important Queen Conch reserve in the Southeastern region of Cuba and an apparently self-sufficient population for recruitment. From our results we may conclude that, the population's sustainable exploitation is viable if the following management measures are observed: functional zoning within the area, rotation of fishing areas and a closed season. We recommend that the Laguna site should be protected as a reproduction zone and banned for fishing activities. Rev. Biol. Trop. 61 (2): 645-655. Epub 2013 June 01.
\end{abstract}

Key words: Caribbean Sea, reproduction evidence, fishery management, protected areas, Eustrombus gigas.

The queen conch Eustrombus gigas (Linnaeus 1758), formerly known as Strombus gigas (Petuch 2004, Petuch \& Roberts 2007), is one of the most valuable coastal resources in the Caribbean region (de Jesús-Navarrete \& OlivaRivera 1997, Theile 2001, Brito-Manzano et al. 2006). This large mollusk has a high aesthetic and ecological value throughout the Caribbean Sea and surrounding areas from Southern Florida in the United States to Brazil (Abbott 1974). The species is one of the most important coastal resources for the region and is second in importance after the spiny lobster (Panulirus argus Latreille 1804) (Appeldoorn 1994a, de Jesús-Navarrete \& Oliva-Rivera 1997).

At the regional level in the Caribbean, over-exploitation and habitat destruction have caused a decrease in abundance of the resource (Glazer \& Kidney 2004), and for that reason, queen conch has been included in Appendix II of the list of Convention on International Trade in Endangered Species of Wild Fauna and Flora (CITES) since 1992 (Stoner et al. 1992, 1996) and in the Red List of Threatened Animals of 
the International Union for Conservation of Nature-IUCN 1994-as a 'commercially threatened' species (Gómez-Campos et al. 2010).

This situation has led to a variety of management measures including the total fisheries closure, closed seasons, catch quotas, and minimum sizes for harvest (Appeldoorn 1994a), as well as the development of its culture as an alternative use and ecological restoration of damaged populations (Davis 2000). Marine protected areas have been established in many countries to protect wild populations (Appeldoorn 1994b, Stoner 1997).

There are many studies of this species in the Caribbean region (Randall 1964, Appeldoorn 1990, Glazer \& Berg 1992, Stoner et al. 1996, Basurto et al. 2005, Jared et al. 2006, Ávila-Poveda \& Baqueiro-Cárdenas 2006, Gómez-Campos et al. 2010, Stoner et al. 2012a), but few have been conducted in Cuba. For the Eastern coast of Cuba, Alcolado (1976) studied the growth, morphological variations of the shell and other biological data. Some commercial fishing assessments were made by Formoso (2001) and Álvarez-Lemus \& Formoso (2005). Recently, Cala (2006) addressed socio-environmental problems associated with this resource, the conflicts of use and impacts over the distribution area of E. gigas at Cabo Cruz. He proposed two strategic guidelines to strengthen the management plan of the Desembarco del Granma National Park focusing on the conch protection as a flagship species.

The reproductive evidence studies (aggregations, mating, spawning and presence of egg masses) are scarce for this species. Stoner \& Ray (2000) carried out a study in The Bahamas, showing a relationship between conch density and frequency of reproduction. For example, no mating was observed when densities were less than 56 adults (ind./ha). Recently, Stoner et al. (2012a) found that similar densities were required for mating in two new study sites (47 and 64 adults ind./ha for Berry Islands and Andros Island in the Bahamas, respectively). At Banco Chinchorro, Mexico, de Jesús-Navarrete et al. (2003) reported very low reproductive activity, also related to the adults low density because of overfishing, and indicated the existence of an Allee effect in the population. At Cabo Cruz, Alcolado (1976) reported an average density of 750ind./ha, which is higher than other Caribbean areas, but he did not report the occurrence of reproductive activities, leaving an information gap for $E$. gigas in Cuban waters.

This paper presents an analysis of adult density, physical variables and reproductive activity for E. gigas at Cabo Cruz, one of the least studied sites of the Cuban archipelago, with the goal of providing information for conch fisheries management in Cuba in this area. The results will contribute to update the management plan of Desembarco del Granma National Park, with relevant information on the reproduction of E. gigas in the study area. It is also the first of its kind in the Southeastern region of Cuba.

\section{MATERIALS AND METHODS}

Study area: Cabo Cruz is located in the Southeastern region of Cuba (19 50'14.1' N - 7744'15.7” W) where the protected area Desembarco del Granma National Park occupies 32 576ha. The study area is located on the reef lagoon of Cabo Cruz, in the most Western region of the park. This lagoon is characterized by extensive sandy bottoms with patches of Thalassia testudinum (Banks \& Sol ex K.D. Koenig) and Syringodium filiforme (Kützing in Hohenacker). There is also significant abundance of some macroalgae species, mainly of the genera Dictyota, Penicillus and Ceramium (Alcolado 1976). Lagoon depth ranges from 0-6m.

Surveys were conducted at three different zones into the reef lagoon: Guafe (19'50'828'

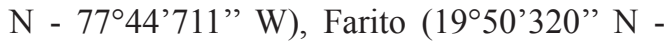
$77^{\circ} 44^{\prime} 581$ 'W) and Laguna (19॰50’225” N - 7744'188" W). In addition, three climatic seasons were analyzed: rainy (May-August), dry (September-December) and cold fronts (January-April, although, these events begin usually after December) (Gónzalez 1999). For this study, we analyzed the cold fronts average 
in the previous year before establishing January-April as the cold front season. Sampling was conducted between July 2009 and September 2010.

For each zone, the water column salinity (UPS, Mean \pm SE) was measured using a portable refractometer (RF20 model) and the Practical Salinity scale. A temperature \& light data logger $\mathrm{HOBO}$ was programmed to take readings every $30 \mathrm{~min}$ of other abiotic variables such as temperature $\left({ }^{\circ} \mathrm{C}, \mathrm{Mean} \pm \mathrm{SE}\right)$, photoperiod (hours, Mean $\pm \mathrm{SE}$ ) and light intensity (lum/ $/ \mathrm{ft}^{2}, \mathrm{Mean} \pm \mathrm{SE}$ ).

Conch sampling: In each study zone three sampling sites were established, each with three transects of $100 \times 2 \mathrm{~m}\left(400 \mathrm{~m}^{2}\right)$. To evaluate conch population density, we measured the perpendicular distance of each conch to the transect line using $1 \mathrm{~m}$ length PVC pipes. The density was calculated using the Distance Sampling software v. 6.0, considering the perpendicular distance and using the cosine function and the normal expansion series (Buckland et al. 1993). The total density and adult density was determined for each zone and season (ind./ ha, Mean \pm SE).The conchs were collected at each zone by free diving. The siphonal length (SL) and the lip thickness (LT) were registered with a caliper with a precision of $0.1 \mathrm{~mm}$.

All conchs were classified as juveniles or adults taking the lip thickness as an indicator of sexual maturity. The range of variation in lip thickness measurement that determines the age at sexual maturity and the onset of adult age are highly variable (Gómez-Campo et al. 2010); this can be $>1 \mathrm{~mm}$ as used by Perez-Perez \& Aldana-Aranda (2000) to $14.2 \mathrm{~mm}$ as used by Appeldoorn (1988). For this study, we took into account the presence of an extended lip and the conchs withlip thickness $<8.0 \mathrm{~mm}$ were classified as juveniles and those with lip thickness $\geq 8.0 \mathrm{~mm}$ as adults (Stoner et al. 2012b).

The absolute frequency of the following reproductive events was recorded at each transect as follows: a) copulation: penis into the female canal, b) spawning: females laying egg mass, c) aggregation: conch group (more than five individuals) and d) egg masses: solitary egg masses (Pérez-Pérez \& Aldana-Aranda 2003 with modifications).

To compare the adult density among zones and seasons, a two-way analysis of variance (ANOVA) was used. Values of salinity and temperature were compared both spatially and temporally with one-way ANOVA. In order to fulfill homoscedasticity requirements, all data were transformed to $\log (\mathrm{x}+1)$. ANOVA was followed by multiple range tests to achieve post hoc comparisons.

Pearson correlation analysis was used to evaluate the possible relationship between reproductive activities. To evaluate the relationship between reproductive activities with abiotic variables, a multiple linear regression analysis was performed; prior this analysis, a Pearson correlation test was accomplished to avoid the use of auto-correlated independent variables (abiotic variables) in the model. The model was constructed using a stepwise backward technique. For the removal of predictor variables we considered as selection criteria the p-value ( 0.05 to 0.1 for add and delete respectively). Statistical tests were performed with Statgraphics Centurion XVI software v. 16.1.03. The statistical differences were considered with a 95\% significance level (Zar 1999).

\section{RESULTS}

The average water temperature was lowest in the dry season in December $\left(26 \pm 0.44^{\circ} \mathrm{C}\right)$ and highest in the rainy season in August $\left(28.8 \pm 0.05^{\circ} \mathrm{C}\right)$ (Fig. 1), statistically significant differences among monthly temperatures were found (ANOVA, $p<0.05$ ). Salinity had minimum values in January (32.4 $\pm 0.4 \mathrm{UPS})$ and maximum in October (35.4 $\pm 0.2 \mathrm{UPS})$ (Fig. 1). No significant differences were detected in salinity either among zones or between season (ANOVA, $\mathrm{p}<0.05$ ).

The photoperiod varied among the study months, with minimum values in November $(10.07 \pm 0.4 \mathrm{hr})$ in dry season and maximum values in July $(12.73 \pm 0.1 \mathrm{hr})$ during the rainy season (Fig. 2). Significant differences were 


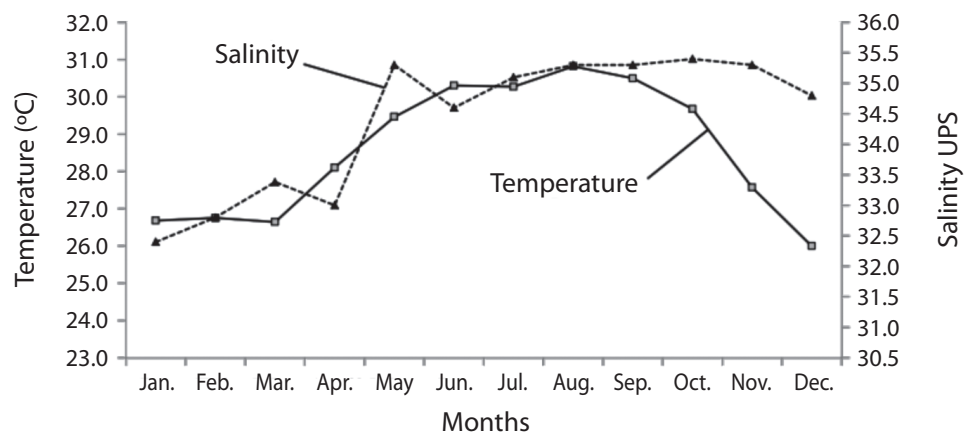

Fig. 1. Monthly variation of average water temperature and salinity at Cabo Cruz, Cuba.

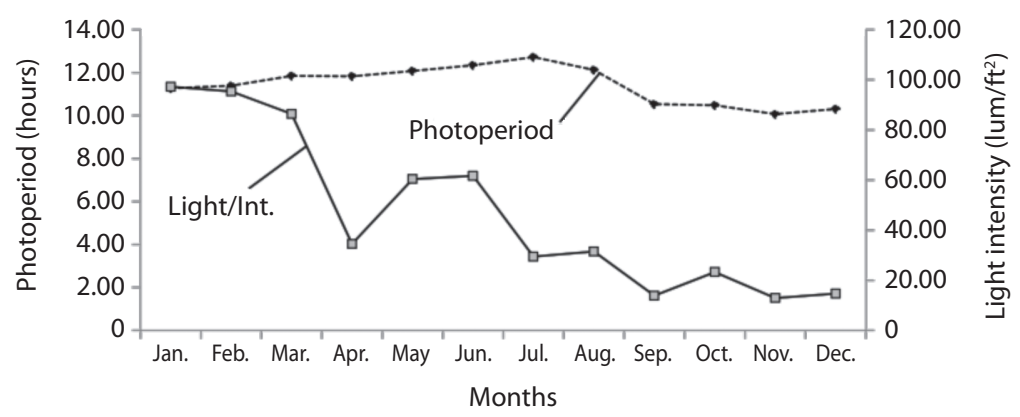

Fig. 2. Monthly variation of average light intensity and photoperiod at Cabo Cruz, Cuba.

detected in photoperiod either among months and climatic seasons (ANOVA, $\mathrm{p}<0.05$ ). A multiple range test was subsequently applied and showed that the cold front season was different from the rainy and dry season.

Light intensity filtered through the water column showed the lowest value in November during the dry season $\left(12.89 \pm 2.81 \mathrm{um} / \mathrm{ft}^{2}\right)$ and maximum $\left(97.24 \pm 6.51 \mathrm{um} / \mathrm{ft}^{2}\right)$ in the cold front season (January) (Fig. 2). Significant differences were detected in light intensity among months and climatic seasons (ANOVA, $\mathrm{p}<0.05)$. A multiple range test confirmed differences among the three seasons.

Density considering the whole population by zone and season at the study area showed higher values at Farito during the dry season (1767 $\pm 213.68 \mathrm{ind} . / \mathrm{ha})$ and lower (247 $\pm 30.4 \mathrm{ind} . / \mathrm{ha})$ at Guafe during the rainy season. No significant differences were detected among seasons (ANOVA, $\mathrm{p}>0.05$ ). Spatial analysis showed that higher density occurred at Farito (1 723 \pm 19.2 ind./ha) and lower at Guafe (511 $\pm 22.3 \mathrm{ind} . / \mathrm{ha})$. No significant differences were detected among zones (ANOVA, $\mathrm{p}>0.05$ ).

Density of adult individuals showed values ranging from 124.96 \pm 9.7 ind./ha at Farito in dry season to $674.07 \pm 122.3 \mathrm{ind}$./ha at Laguna during the cold fronts season. The highest density for season was observed in cold fronts season (468.5 \pm 53.3 ind./ha) and lowest in the dry season $(268.5 \pm 24.5 \mathrm{ind}$./ha). For the study zone, the adults highest density was observed at Laguna (520.4 $\pm 10.1 \mathrm{ind} . / \mathrm{ha})$ and lowest at Farito (290.9 \pm 19.2ind./ha) (Fig. 3). There were no significant differences either between areas or between seasons in the adult's density (ANOVA, $\mathrm{p}>0.05$ ).

During the whole three seasons we observed 158 reproductive events. The highest 


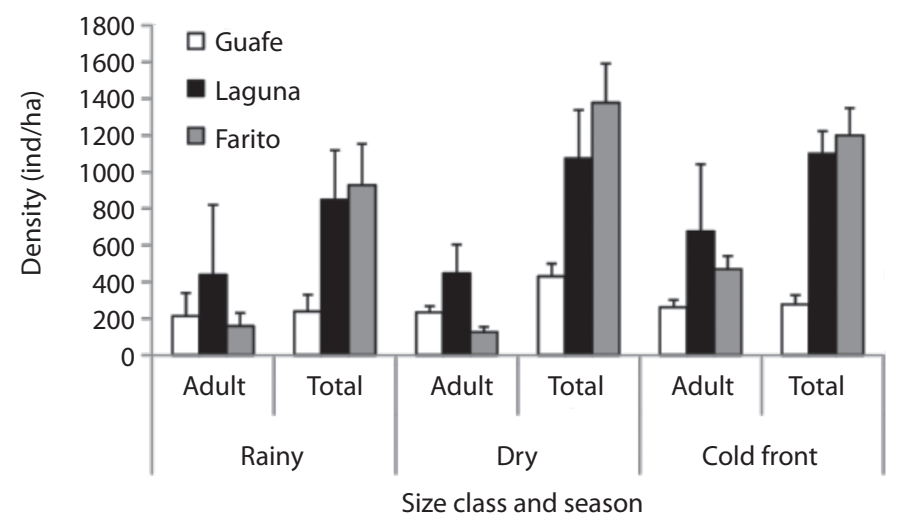

Fig. 3. Mean total and adult conch densities $( \pm$ standard error) at each zone during the three climatic seasons.

frequency of reproductive events was observed in the rainy season $(36 \%)$, followed by dry (9\%) and cold front (5\%) (Fig. 4A). Spatially, a total of 73 adult aggregations of more than five individuals were reported, distributed at the study zone during the three seasons, although they were observed much more often at Laguna and Farito (6\% and 10\%, respectively) (Fig. 4B). Copulation was observed on 25 occasions.

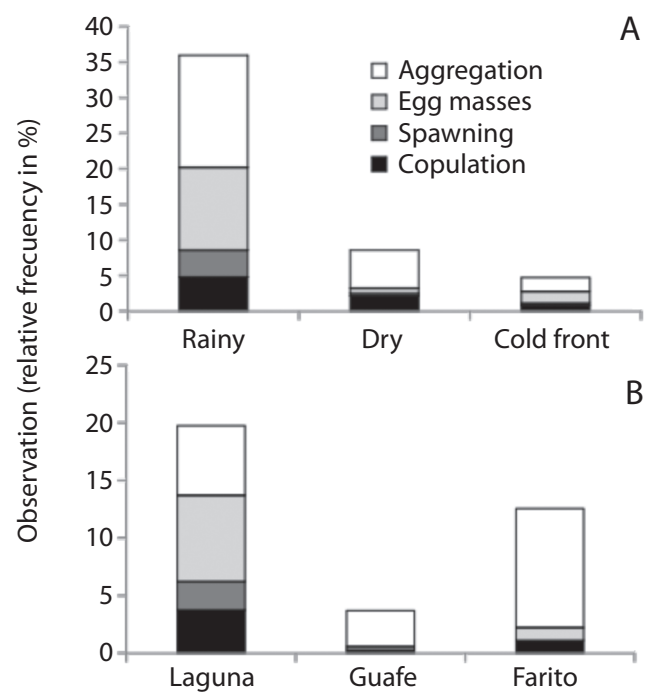

Fig. 4. Relative frequency of the reproductive events at each climatic season (A) and each study zone (B) at Cabo Cruz, Cuba.
Only one copulation was observed at Guafe during the study $(0.3 \%)$ and other three copulation were observed at Farito (1.2\%); however, this reproductive evidence was more frequent at Laguna (3.7\%). It is important to note that Laguna was the only site where we observed spawning activities $(2.5 \%)$ and 42 egg masses $(7.5 \%)$. The rest of the egg masses were observed at Farito (1.2\%) and Guafe $(0.3 \%)$.

We found a significant correlation between the frequency of spawning and mating at the study area $(\mathrm{r}=0.84, \mathrm{p}=0.0012, \mathrm{n}=81)$ and between the copulation frequency and the absolute number of egg masses $(r=0.73$, $\mathrm{p}=0.0161, \mathrm{n}=81)$. The rest of the reproductive evidence did not show correlations (Pearson, $\mathrm{p}>0.05$ ) (Table 1).

The absolute frequency of aggregations was positively correlated with photoperiod $(\mathrm{r}=0.39, \mathrm{p}<0.05)$, just as occurred with the frequency of mating $(\mathrm{r}=0.40, \mathrm{p}<0.05)$, likewise, the temperature was positively correlated with the number of egg masses $(r=0.52, p<0.05)$ and spawning frequency $(\mathrm{r}=0.35, \mathrm{p}<0.05)$. The multiple regression models explained significantly $23 \%$ of the variance of the aggregation frequency and $12 \%$ in the copulation frequency, including the photoperiod as predictor variable that affect both aggregations frequency and copulation frequency directly. Similarly, the multiple regression models explained 
TABLE 1

Pearson correlation between reproductive evidence of E. gigas at Cabo Cruz

\begin{tabular}{llcccccccc} 
& \multicolumn{2}{c}{ Copulation } & \multicolumn{2}{c}{ Spawning } & \multicolumn{2}{c}{ Egg masses } & \multicolumn{2}{c}{ Aggregation } \\
& $\mathrm{r}$ & $\mathrm{p}$ & $\mathrm{r}$ & $\mathrm{p}$ & $\mathrm{r}$ & $\mathrm{p}$ & $\mathrm{r}$ & $\mathrm{p}$ \\
Copulation & & & 0.8357 & $0.0012^{*}$ & 0.4357 & 0.0621 & 0.3350 & 0.0876 \\
Spawning & & & & & 0.7341 & $0.0161^{*}$ & 0.2496 & 0.2093 \\
Egg masses & & & & & & & & 0.2004 & 0.3161 \\
\hline
\end{tabular}

Correlation coefficients (r), p-value associated with each test (p) and $(*)$ indicates significant correlation.

TABLE 2

Multiple regression analysis to predict the abundance of the reproductive evidence of E. gigas at Cabo Cruz

\begin{tabular}{|c|c|c|c|c|}
\hline & Temperature & Photoperiod & Salinity & Light int. \\
\hline $\begin{array}{r}\text { Aggregation frec. } \\
\mathrm{r}^{2} \text { adjusted } \\
\text { MAE } \\
\mathrm{F}\end{array}$ & ns & $\begin{array}{c}0.23 \\
0.51 \\
8.69(0.056)^{*}\end{array}$ & - & ns \\
\hline $\begin{array}{r}\text { Copulation frec. } \\
\mathrm{r}^{2} \text { adjusted } \\
\text { MAE } \\
\mathrm{F}\end{array}$ & ns & $\begin{array}{c}0.12 \\
0.46 \\
4.44(0.055)^{*}\end{array}$ & - & ns \\
\hline $\begin{array}{r}\text { Egg masses frec. } \\
\mathrm{r}^{2} \text { adjusted } \\
\text { MAE } \\
\mathrm{F}\end{array}$ & $\begin{array}{c}0.24 \\
0.47 \\
9.38(0.052)^{*}\end{array}$ & ns & - & ns \\
\hline $\begin{array}{r}\text { Spawning frec } \\
\mathrm{r}^{2} \text { adjusted } \\
\text { MAE } \\
\mathrm{F}\end{array}$ & $\begin{array}{c}0.12 \\
0.27 \\
3.58(0.070)^{*}\end{array}$ & ns & - & ns \\
\hline
\end{tabular}

( $\mathrm{r}^{2}$ adjusted: adjusted coefficient of determination, MAE: absolute average error of the test; F: ANOVA f-ratio; ns: variable removed (not significant); (---) variable not included in the regression analysis; ${ }^{*} \mathrm{p}<0.05$ ).

significantly the $24 \%$ of the variance in the number of egg masses and $12 \%$ in spawning frequency, including in both cases the temperature as a predictor variable (Table 2).

\section{DISCUSSION}

Important variations in density have been reported, both in populations of E. gigas subjected to exploitation by fisheries, as in those located in non-take areas and have been attributed primarily to fluctuations in the environmental conditions, biological interactions and the fishing pressure (Weil \& Laughling 1984, Gómez-Campos et al. 2005). In other cases, changes have been associated with variations in recruitment (Roughgarden et al. 1988, de Jesús-Navarrete et al. 2003). Mean density considering the whole population at the study area was higher (1 $108 \pm 207 \mathrm{ind}$./ha) than other areas of the Caribbean. In despite that statistical analysis showed no significantly differences in density among zones, the adult density at Laguna represented up to $52 \%$ of the total density of the study area indicating that these conchs have a preference for that zone. At a seasonal scale, there were no differences in density maybe related with the protection regime that exist at Desembarco del Granma National Park.

Chiquillo-Espitia et al. (1997) found that $18 \%$ of the conchs with lip thickness $\geq 5 \mathrm{~mm}$ in three fishing zones at Colombia were still 
immature. In addition, the estimated age at which the conch produces the flared lip is among 3-3.5 years, although it varies between populations and depending on the environmental factors that regulate growth (Alcolado 1976, Appeldoorn 1988). Even after the lip is fully formed, the reproduction capacity is reached some month later (Hesse 1976, Egan 1985, Appeldoorn 1988). In this sense, we have been conservative in the morphometric selection of adult, pending that the necessary histological studies must be performed in this zone, allowing good criteria in the differentiation of adult population.

Appeldoorn (1988) proposed three possible mechanisms to explain the relationship between adult conch density and reproductive success, all related to the density of breeding adults, and Stoner et al. (2012a) mentioned that it is necessary to maintain a density higher than 100ind./ha to ensure reproduction. Although these parameters may vary geographically, adult densities reported in this study are higher than the minimum threshold and consequently the frequency of reproductive activities is high.

The low density of adults at Farito in dry season may be explained for the fact that adult conch carry out an ontogenetic migration to deeper zones and then they return to shallow waters to breed (Lagos-Bayona 1994, de JesúsNavarrete et al. 2003). Samplings were conducted on November and Farito is located very close to the communication channel between the reef lagoon and the open sea, and it is possible at that time the migration to shallow areas may not yet have begun. In turn, Laguna presented the highest density of adult conch in cold front season which could be related to the initiation of reproductive aggregations that showed a peak immediately after that, in the rainy season (Fig. 4A). Guafe did not showed high adult density or reproductive evidence, although we observed some of this evidence and that there were also adults groups, this zone can be managed as a "sacrifice zone" for the fishery management of the conch at Cabo Cruz.

Despite the high total density of adults in this study, the fishery management strategies for E. gigas should be focused to catch only the excess production or even to set a quota below this excess, taking into account the local needs and maintaining an abundance level on the population, where the reproductive encounter rate be maintained above the lower limit of possible mating (Appeldoorn 1988, Dugan \& Davis 1993, Basurto et al. 2000). This avoids the population imbalance, to maintain the global biomass and to prevent the decrease on size and sexual maturity (Harmelin et al. 1995). Recent studies suggest a sustainable exploitation of the conch as a management strategy to minimize the size decrease of individuals due to the possible impact of crowding (Bene $\&$ Tewfik 2003). Furthermore, it promotes the maintenance of an annual recruitment rate, avoiding the consequent reduction in fertility due to low encounter rate between breeding pairs (Allee effect), changes that could be induced by overfishing of the conch (Roberts \& Polunin 1991, Alcalá 1998, de Jesús-Navarrete et al. 2003, Stoner et al. 2012a). Many of these changes have been observed in stocks subject to fishing pressure (de Jesús-Navarrete et al. 2003, Stoner et al. 2012a) and must be taken into consideration when planning a sustainable fishery of conch at Cabo Cruz.

The high density of adults conch in all study zones and the low variability of the physical parameters with exception for the light intensity filtering through the water column, combined with the favorable characteristics of the substrate, seems to promote good conditions for the reproduction of E. gigas (Alcolado 1976) and has been possible to observe reproductive activity throughout the year. The wider reproduction period (aggregation, mating, spawning females and egg masses) has been reported the year round by Cruz (1986) and Corral \& Ogawa (1987) at Banco Chinchorro, Mexico. The shortest period (MaySeptember) was reported at Florida (D'Assaro 1965) and other variations have been reported in the reproduction period for different parts of the Caribbean (Randall 1964, Appeldoorn et al. 1987, Davis et al. 1987, Stoner et al. 1992, Weill \& Laughling 1994). 
High reproductive activity during the rainy season at Laguna was observed, possibly, because it is protected by the reef crest and has substrate with a predominance of sand and patches of T. testudinum, according to Alcolado (1976) this characteristics are suitable for the conch reproduction. Guafe, in shallow waters, has the influence of runoff and the substrate is muddy with much sediment in suspension and Farito is a transition zone between the shallow zone of Laguna and the deep zone of Cabo Cruz, with substrate entirely covered with dense seagrass, so none of the two zones are adequate for the reproduction. Even with these results, it would be useful to develop more detailed studies that allow the identification of reproductive peaks throughout the year and a more appropriate species management.

Reproductive activity and abiotic factors: In the most of animal species the periods of reproduction activity are determined by daylight variations along the year (photoperiod), temperature, food availability and ecological interactions (Martinet \& Mondain-Monval 1991). Reproductive evidence was observed along the year in this study but was more abundant during the rainy season when temperatures were higher. It was also found, that a direct relationship exists between the number of aggregations and the photoperiod as well as between mating frequency and photoperiod; most of the groups and organisms mated when the daylight exceed $12 \mathrm{hr}$. Stoner et al. (1992) found a linear direct relationship between mating frequency and temperature and they suggested that, as with temperature, photoperiod may influence the production of mature gametes or have a direct effect on the behavior of conch. Light intensity does not seem to have an effect over the frequency of reproductive activities, but it is recommended a deeper study in this issue.

Spawning frequency and the amount of egg masses increases proportionally with temperature showing the importance of this variable in the reproduction of E. gigas as reported by several authors (Alcolado 1976, Stoner et al. 1992, Davis 1998). The significant relationship between mating and spawning frequencies corroborates, in a way, one of the mechanisms proposed by Appeldoorn (1988) that refers a positive feedback between spawning and gametogenesis in females. According to the hypothesis of Appeldoorn (1988), copulation stimulates oocyte development and maturation, leading more frequent spawning.

It is considered that the number of aggregations per zone is related with the search for mating (Brownell \& Stevely 1981) and could be linked to food abundance at the substrate features instead of the reproductive activity (Alcolado 1976). Nevertheless it is possible that Guafe has higher values of organic matter in the sediment in relation with the other zones because of coastal runoff (Cala 2006) and a high number of groups feeding should be expected but this did not happen. In Cabo Cruz exists an intense reproductive activity of $E$. gigas all year round with a high density of adult conchs in the three studied zones. This suggest not only an important stock for this species it the Southeastern shelf of Cuba else a possible self-sufficiency of this population to guarantee a relatively stable recruitment too.

From the previous, an adequate regulatory exploitation of the population is viable taking into account that the Laguna site reached the higher absolute frequency of reproductive evidences during the study period, mostly during the rainy season (March-June). This aspect is important for the establishment of temporal closures and the functional zonation of the protected area. In addition, Laguna zone must be proposed as a reproductive activity area, and Guafe and Farito as potential fishing areas with a closure season from March to June. To conduct a wider spatial and temporal study will first benefit the knowledge of the distribution of this species and second the decision making because it could be proposed a yearly rotation of the fishing zones and a monitoring program of E. gigas and its habitat as part of the National Park Management Plan (Cala 2006). 


\section{ACKNOWLEDGMENTS}

This research was conducted under the support of Consejo Nacional de Ciencia y Tecnología, México, doctoral concession number 228610. Centro Nacional de Áreas Protegidas de Cuba gave field materials. We thank the useful assistance of C. Ocano, O. De la Hera and A. Galindo during field work. Comments of A.W. Stoner, P.M. Alcolado, J.C. Pérez, D. Gonzales and M. Mendoza contributed to improve the manuscript.

\section{RESUMEN}

El Eustrombus gigas es un recurso pesquero importante en la región del Caribe. En Cuba, los estudios acerca de este recurso son muy escasos y en la zona Sur-oriental del país son casi nulos. En este trabajo se evalúa la densidad de adultos y frecuencia de la evidencia reproductiva de Eustrombus gigas Linneus 1758 en Cabo Cruz, Cuba, en el periodo 2009-2010. Se obtuvieron datos de tres períodos (lluvias, seca y frentes fríos) en tres zonas: Farito, Guafe y Laguna. La mayor densidad de adultos se observó en frentes fríos (468.5ind./ha) y la menor en seca (268.5ind./ ha). Por zonas, la mayor densidad de adultos se reportó en Laguna (520.4ind./ha) y la menor en Farito (290.9ind./ha). Se observaron 158 evidencias reproductivas. La mayor frecuencia se reportó en lluvias (36\%). La temperatura se relacionó con la frecuencia de desove y cantidad de masas de huevos, y el fotoperiodo con la cantidad de agregaciones y frecuencia de cópula. Se observó actividad reproductiva intensa durante todo el año, lo que sugiere una importante reserva de la especie en la región sur-oriental de Cuba y una aparente autosuficiencia de la población para el reclutamiento. La explotación sostenible de la población es viable y Laguna debe ser protegida como zona de reproducción.

Palabras clave: Mar Caribe, reproducción, manejo pesquero, áreas protegidas, Eustrombus gigas.

\section{REFERENCES}

Abbott, R.T. 1974. American seashells. Van Nostrand Reinhold, New York, USA.

Alcalá, A.C. 1988. Effects of marine reserves on coral fish abundance and yields of Philippine coral reefs. Ambio 17: 194-199.

Alcolado, P.M. 1976. Growth, morphological variations of the shell and some biological data of the conch (Cobo) Strombusgigas L. (Mollusca, Mesogastropoda). Acad. Cienc. Cub. Ser. Oceanol. 34: 1-36.
Álvarez-Lemus, J.A. \& M. Formoso. 2005. Gestión del Strombus gigas (Linnaeus, 1758) en la República de Cuba. CITES, La Habana, Cuba.

Appeldoorn, R.S. 1990. Growth of juvenile queen conch Strombus gigas L., of La Parguera, Puerto Rico. J. Shellfish Res. 9:59-62.

Appeldoorn, R.S. 1994a. Queen conch management and research: status, needs and priorities, p. 301-319. In R.S. Appeldoorn \& B. Rodriguez (eds.). Queen Conch Biology, fisheries and mariculture. Fundación Científica Los Roques, Caracas, Venezuela.

Appeldoorn, R.S. 1994b. Spatial variability in the morphology of Queen Conch and its implication for management regulations, p. 145-157. In R.S. Appeldoorn \& B. Rodríguez (eds.). Queen Conch biology, fisheries and mariculture. Fundación Científica Los Roques, Caracas, Venezuela.

Appeldoorn, R.S., G.D. Dennis \& O. Monterrosa-Lopez. 1987. Review of shared demersal resources of Puerto Rico and the Lesser Antilles region, p. 36-57. In R. Mahon (ed.). Report and proceedings of the expert consultation of shared fishery resources of the Lesser Antilles region. FAO Fish. Rep.

Ávila-Poveda, O.H. \& E.R. Baqueiro-Cárdenas. 2006. Size at sexual maturity in the queen conch Strombus gigas from Colombia. Bol. Invest. Mar. Cost. 35: 223-233.

Basurto-Origel, M., O. Cruz-Domínguez, D. MartínezVázquez \& P. Cadena-Romero. 2000. Caracol, p. 712-744. In M.A. Cisneros-Mata, L.F. BeléndezMoreno, E. Zárate-Becerra, M.T. Gaspar-Dillanes, L. López-González, C. Saucedo-Ruíz \& J. Tovar-Ávila (eds.). Sustentabilidad y pesca responsable en México; evaluación y manejo. INP-SAGARPA, México.

Basurto-Origel, M., P. Cadena, G. Escobedo \& F. Fernández. 2005. Evaluación de la población de Strombus gigas en los bancos de Cozumel y Chinchorro y recomendaciones para su aprovechamiento sostenible. Instituto Nacional de la Pesca, Puerto Morelos, México.

Brito-Manzano, N., D. Aldana-Aranda, E. de la CruzLazaro \& M. Estrada-Botello. 2006. Organogénesis larvaria de Strombus gigas (Mesograstropoda: Strombidae) en el arrecife Alacranes durante el periodo máximo de su época reproductiva. Univ. Ciencia 22: 75-82.

Buckland, S.T., D.R Anderson, K.P Burnham \& J.L. Laake. 1993. Distance sampling estimating abundance of biological populations. Chapman \& Hall, Londres, Inglaterra.

Cala, Y.R. 2006. Bases para el manejo integrado del Strombus gigas L. 1758 en el sector costero Monigote-Las Coloradas, Cuba. Tesis de Maestría, Universidad de Oriente, Santiago de Cuba, Cuba. 
Corral, J.L. \& J. Ogawa. 1987. Cultivo masivo de larvas de caracol Strombus gigas en estanques de concreto. Proc. Gulf Caribb. Fish. Inst. 38: 345-351.

Cruz, R. 1986. Avances en la experimentación de producción masiva de caracol en Quintana Roo, México. Proc. Gulf Caribb. Fish. Inst. 37: 12-20.

D’Assaro, C.N. 1965. Organogenesis, development, and metamorphosis in the queen conch, Strombus gigas, with notes on breeding habits. Bull. Mar. Sci. 15: 359-416.

Davis, M., C. Hesse \& G. Hodgkins. 1987. Commercial hatchery produced queen conch, Strombus gigas, seed for the research and grow-out market. Proc. Gulf Caribb. Fish. Inst. 38: 326-335.

Davis, M. 1998. The effects of natural foods, temperature and salinity on the length of larval life for the tropical gastropod Strombus gigas. Tesis de Doctorado, Florida Institute of Technology, Florida, USA.

Davis, M. 2000. The combined effects of temperature and salinity on growth, development, and survival for tropical gastropod veligers of Strombusgigas. J. Shellfish Res. 19: 883-889.

de Jesús-Navarrete, A. \& J. Oliva-Rivera. 1997. Densidad, crecimiento y reclutamiento del caracol rosado Strombus gigas L. (Gasterópoda: Strombidae) en Quintana Roo, México. Rev. Biol. Trop 45: 797-801.

de Jesús-Navarrete, A., A. Medina-Quej \& J. Oliva-Rivera. 2003. Changes in the queen conch (Strombus gigas L.) population structure at Banco Chinchorro, Quintana Roo, Mexico, 1990-1997. Bull. Mar. Sci. 73: 219-229.

Dugan, J.E. \& G.E. Davis. 1993. Applications of marine refugia to coastal fisheries management. J. Fish. Aquat. Sci. 50: 2029-2042.

Formoso, M. 2001. Stock assessment and fishery management of queen conch Strombus gigas in major fishing grounds of the Cuban Shelf. Queen Conch Conference, Juan Dolio, Puerto Rico.

Glazer, R. \& C.J. Berg Jr. 1992.Growth and mortality of the queen conch, Strombus gigas, in Florida, a progress report. Proc. Gulf Caribb. Fish. Inst. 42: 153-157.

Glazer, R. \& J.A. Kidney. 2004. Habitat associations of adult queen conch (Strombus gigas L.) in an unfished Florida Keys back reef: applications to essential fish habitat. Bull. Mar. Sci. 75: 205-224.

Gómez-Campo, K., M. Rueda, C. García-Valencia, F. Ballesteros \& L.E. Mejía. 2005. Densidad y distribución de la estructura poblacional de Strombus gigasLinnaeus, 1758 (Mollusca: Strombidae) asociada a diferentes hábitats en el Archipiélago Nuestra Señora del Rosario, Caribe colombiano. Proc. Gulf Caribb. Fish. Inst. 58: 399-406.

Gómez-Campo, K., M. Rueda \& C. García-Valencia. 2010. Distribución espacial, abundancia y relación con características del hábitat del caracol Pala Eustrombus gigas (Linnaeus) (Mollusca: Strombidae) en el archipiélago Nuestra Señora del Rosario, Caribe Colombiano. Bol. Invest. Mar. Cost. 39: 137-159.

Gónzalez, P.C. 1999. Climatología de los frentes fríos que han afectado a Cuba desde 1916-17 hasta 1996-97. Rev. Cub. Met. 6: 15-19.

Harmelin, J.G., F. Bachet \& F. García. 1995. Mediterranean marine reserves: fish indices as a test of protection efficiency. Mar. Ecol. 16: 233-250.

Jared, M., M. Taylor, K. Roy \& M. Hellberg. 2006. A molecular phylogenetic analysis of strombid gastropod morphological diversity. Mol. Phylogenet. Evol. 41: 436-434.

Lagos-Bayona, A.L. 1994. Algunos aspectos biológicos y pesqueros del caracol pala Strombus gigasLinnaeus, 1758 (Mollusca: Gastropoda: Strombidae), en el Archipiélago de San Bernardo y ensayos sobre su cultivo en laboratorio. Tesis de Licenciatura, Universidad de Bogotá, Bogotá, Colombia.

Martinet, L. \& M. Mondain-Monval. 1991. Rythmes de reproduction etfacteurs de l'environnement, p. 589-610. In C. Thibault \& M.C. Levasseur (eds.). La reproductionchez les mammíferes et l'homme. Ellipses-INRA, París, Francia.

Pérez-Pérez, M. \& D. Aldana-Aranda. 2003. Actividad reproductiva de Strombus gigas (Mesogasteropoda: Strombidae) en diferentes hábitats del Arrecife Alacranes, Yucatán. Rev. Biol. Trop. 51: 119-126.

Petuch, E.J. 2004.Cenozoic Seas. The View from Eastern North America. CRC, Boca Raton, Florida, USA.

Petuch, E.J. \& C.E. Roberts. 2007. The Geology of the Everglades and Adjacent Areas. CRC, New York, USA.

Randall, J.E. 1964. Contributions to the biology of the queen conch, Strombus gigas. Bull. Mar. Sci. 14: 246-295.

Roberts, C.M. \& N.V. Polunin. 1991. Are marine reserves effective in management of reef fisheries? Rev. Fish. Biol. Fish. 1: 65-91.

Roughgarden, J., S. Ganes \& H. Possingham. 1988. Recruitment dynamics in complex life cycles. Science 228: 1460-1466.

Stoner, A.W. 1997.The Status of Queen Conch, Strombus gigas, Research in the Caribbean. Mar. Fish. Rev. 59: $14-22$.

Stoner, A.W. \& M. Ray. 2000. Evidence for Allee effects in an over-harvested marine gastropod: densitydependent copulation and egg production. Mar. Ecol. Prog. Ser. 202: 297-302.

Stoner, A.W., V.J. Sandt \& I.F. Boidron-Metairon. 1992. Seasonality in reproductive activity and larval 
abundance of queen conch Strombus gigas. Fish. Bull. 90: 161-170.

Stoner, A.W., M. Ray, R.A. Glazer \& K.J. McCarthy. 1996. Metamorphic responses to natural substrata in a gastropod larva: decisions related to post-larval growth and habitat preference. J. Exp. Mar. Biol. Ecol. 205: 229-243.

Stoner, A.W., M. Davis \& C.J. Booker. 2012a. Negative consequences of Allee Effect are compounded by fishing pressure: comparison of queen conch reproduction in fishing grounds and a marine protected area. Bull. Mar. Sci. 88: 89-104.

Stoner, A.W., K.M. Mueller, N.J. Brown-Peterson, M.H. Davis \& C.J. Booker. 2012b. Maturation and age in queen conch (Strombus gigas): urgent need for changes in harvest criteria. Fish. Res. 131-133: 76-84.
Theile, S. 2001. Queen conch fisheries and their management in the Caribbean. TRAFFIC Europe, CITES, Bruselas, Bélgica.

Weil, M.E. \& R. Laughlin. 1984. Biology, population dynamics, and reproduction of the queen conch Strombus gigas Linné in the Archipiélago de Los Roques National Park. J. Shellfish Res. 4: 45-62.

Weil, E. \& R.A. Laughlin. 1994. Laboratory cultures of larvae of Strombus gigas L. in the Dos Mosquises Marine Station, Los Roques National Park, Venezuela: final results, p. 275-293. In R.S. Appeldoorn \& B. Rodríguez (eds.). Queen conch biology, fisheries and mariculture. Fundación Científica Los Roques, Caracas, Venezuela.

Zar, J.H. 1999. Biostatistical Analysis. Prentice-Hall, Upper Saddle River, USA. 
